\title{
RELIABLE CO-SEGREGATION ANALYSIS FOR PRENATAL DIAGNOSIS AND HETEROZYGOTE DETECTION IN GAUCHER DISEASE
}

\author{
B. CORMAND ${ }^{1}$, M. MONTFORT ${ }^{1}$, A. CHABÁS ${ }^{2}$, D. GRINBERG ${ }^{1}$ AND LL. VILAGELIU ${ }^{1 *}$ \\ ${ }^{1}$ D epartament de Genètica, U niversitat de Barcelona, Barcelona, Spain \\ Institut de Bioquímica Clínica, Corporació Sanitaria, Barcelona, Spain
}

Received 5 M arch 1997

Revised 29 M ay 1997

A ccepted 20 J une 1997

\begin{abstract}
SU M M ARY
$M$ utations in the gene encoding $\beta$-glucocerebrosidase are the main cause of $\mathrm{G}$ aucher disease. The identification of some of these mutations in prenatal tests is a good complement to enzymatic assay and allows diagnosis and, in some cases, prognosis of the disease to be made. DNA analysis is particularly useful for carrier detection since the results of biochemical analyses are often ambiguous. The main drawback of mutation analysis for prenatal diagnosis and carrier detection in $\mathrm{G}$ aucher disease is that rare mutations account for more than 30 per cent of the mutant alleles in most populations. The individual detection of these mutations is too expensive and time-consuming for routine use. $\mathrm{H}$ ere we present a diagnostic protocol based on co-segregation analysis, using highly polymorphic markers, to be applied when at least one disease allele does not correspond to the most common mutations. Because of the frequency of the N $370 \mathrm{~S}$ mutation and its relevance for prognosis, an improved PCR detection method is included. (C) 1998 John Wiley \& Sons, Ltd.
\end{abstract}

KEY WORDS: Gaucher disease; co-segregation analysis; microsatellite prenatal diagnosis; mutation analysis; heterozygote detection

\section{INTRODUCTION}

Gaucher disease (GD) is the most prevalent form of sphingolipidosis and is caused mainly by mutations in the gene coding for $\beta$ glucocerebrosidase (GBA; EC 3.2.1.45). It is inherited in an autosomal recessive manner. Three clinical types have been distinguished on the basis of the absence (type 1) or presence and severity of neuronopathic manifestations (types 2 and 3 ) (Beutler and Grabowski, 1995).

Following the first prenatal enzymatic diagnosis accomplished by Schneider et al. (1972), analysis

\footnotetext{
*Correspondence to: Dr Lluïsa Vilageliu, Departament de G enètica, F acultat de Biologia, U niversitat de Barcelona, A v. Diagonal 645, E-08071 Barcelona, Spain.

Contract grant sponsor: $\mathrm{CICYT}$; Contract grant number: SA F 96-0329.
}

of $\beta$-glucocerebrosidase activity in cells derived from amniocentesis or chorionic villus biopsy is routinely performed for the identification of an affected fetus. M ore recently, mutation analysis of fetal DN A has provided new tools for the prenatal molecular diagnosis of GD (Dahl et al., 1992; Zimran et al., 1995).

GD is particularly prevalent among A shkenazi J ews. In this population, a small number of mutations account for most of the mutant alleles. However, in other populations more than 30 per cent of the GD alleles correspond to a variety of rare mutations. Therefore, prenatal molecular diagnosis based on the identification of known mutations is not feasible in many cases.

Twelve internal polymorphisms have been described within the GBA gene (Beutler et al., 1992). However, they are in strong linkage disequilibrium and only two major haplotypes, 
named + and - have been found. Thus, these polymorphisms could be considered a single diallelic marker with only limited interest for co-segregation analysis.

We have recently localized the GBA gene in relation to a series of microsatellite markers (Cormand et al., 1997). The fine genetic mapping of the GBA gene allows the use of highly informative markers for co-segregation analysis when the most common mutations have been ruled out, for one or both GD alleles, in a given family. Here we present two examples in which the patients bear uncommon mutations, to show the applicability of the method for prenatal diagnosis and detection of heterozygous carriers in families segregating GD. In addition, one of the families carrying the $N 370$ S ( $C D N A$ nt $1226 \mathrm{~A} \rightarrow \mathrm{G}$ ) mutation was studied in order to demonstrate an improved polymerase chain reaction (PCR) method, which includes an internal control of digestion.

\section{MATERIALS AND METHODS}

\section{Patients}

Two Spanish GD families were examined to test the diagnostic method described in this paper. Both consisted of the parents, one affected child (proband), and a second child (or fetus) for whom prenatal or carrier diagnosis could have been performed as presented. The patient in family 1 (type 1 ) bore the common N370S mutation in one chromosome while the other allele corresponded to a rare GD mutation. The patient in family 2 presented with type $2 \mathrm{GD}$, and neither of the mutant alleles carried N 370S or L 444P (nt 1448 $T \rightarrow C$ ), the two most frequent $G D$ mutations in the Spanish population. Instead, one allele corresponded to the third most prevalent mutation: D 409H (nt $1342 \mathrm{G} \rightarrow \mathrm{C}$ ), and the other to a rare mutation (Chabás et al., 1996). In this case, prenatal enzymatic diagnosis showed that the fetus was affected, and the pregnancy was interrupted. The clinical aspects of these two patients were referred to as I.11 (family 1 ) and II.6 (family 2 ) in Cormand et al. (1995).

\section{DNA isolation}

Genomic DNA was prepared from peripheral blood leukocytes or a chorionic biopsy specimen (CVS) at gestational week 10 by a standard method (M iller et al., 1988).

\section{A nalysis of mutation N 370 S}

A n improved PCR method to detect the N 370 S mutation, which included an internal control of digestion, was developed. The upstream primer contained a single mismatch (Beutler et al., 1990) that creates an $\mathrm{Xhol}$ restriction site when the mutation is present. The downstream primer is as follows: 5' GTAGATGCTAAGTCCTCGAGGA TGGGACTGTCGACAAAGT 3'. The underlined sequence corresponds to nucleotides 5919-5938 of the gene, according to the sequence reported by H orowitz et al. (1989). M ost of this $20 \mathrm{bp}$ sequence is not present in the highly homologous pseudogene. The rest of the primer was added to incorporate an $\mathrm{X}$ hol restriction site (bold). Fifty microlitres of PCR amplification mixture [containing $100 \mathrm{ng}$ of genomic DNA, $0.2 \mathrm{~mm}$ dNTPs, $1.5 \mathrm{mM} \mathrm{M} \mathrm{gCl}_{2}, 20 \mathrm{pmol}$ of each primer, and $1 \mathrm{U}$ of Dynazyme DNA polymerase (Finnzymes $O y$ ) in the recommended buffer] was subjected to 35 cycles of $94^{\circ} \mathrm{C}$ for $40 \mathrm{~s}$ and $55^{\circ} \mathrm{C}$ for $30 \mathrm{~s}$. A further 2 min extension at $72^{\circ} \mathrm{C}$ was added to the final cycle. Five microlitres of the PCR product was digested with $10 \mathrm{U}$ of $\mathrm{Xhol}$ for $2 \mathrm{~h}$ at $37^{\circ} \mathrm{C}$ and subjected to electrophoresis on a 12 per cent acrylamide-bisacrylamide (19:1) gel (a similar result was obtained using agarose gels- $\mathrm{N}$ uSieve, 4 per cent). The size of the amplified fragment was $138 \mathrm{bp}$. When the N $370 \mathrm{~S}$ mutation is not present, the $\mathrm{X}$ hol site in the downstream primer produces a fragment of $121 \mathrm{bp}$ and a small fragment of $17 \mathrm{bp}$. If the N 3705 mutation is present, an additional $X$ hol site is created by the mismatched primer, giving one fragment of $104 \mathrm{bp}$ and two of $17 \mathrm{bp}$.

\section{A nalysis of mutations L 444P and D 409H}

$D$ etection of $L$ 444P was carried out as described by Sidransky et al. (1992) and analysis of D 409H is described elsewhere (Chabás et al., 1995).

\section{M icrosatellite analysis}

$M$ icrosatellite markers ( $\mathrm{Dib}$ et al., 1996) D 1S305, D 1S2777, D 1S2721, D 1S2140, D 1S2624, D 1S2715, D 1S506, and D 1S2635, located close to the GBA gene (Cormand et al., 1997), were analysed. D etailed information on these markers is given in Table $\mathrm{I}$. The recombination fraction and lod score values between the GBA gene and some of these markers are as follows: D 1S305 
Table I-Polymorphic markers useful for co-segregation analysis in $\mathrm{G}$ aucher disease

\begin{tabular}{|c|c|c|c|}
\hline M arker & Type & $\begin{array}{l}\text { No. of alleles/ } \\
\text { range in bp }\end{array}$ & $\mathrm{H}$ et* \\
\hline $\begin{array}{l}\text { D 1S2715 } \\
\text { D 1S305 } \\
\text { D 1S2777 } \\
\text { D 1S2721 } \\
\text { D 1S2140 } \\
\text { D 1S2624 } \\
\text { D 1S506 } \\
\text { D 1S2635 } \\
\text { PKLR } \\
\text { GBA }\end{array}$ & $\begin{array}{c}\text { (AC)n } \\
\text { (AC)n } \\
\text { (AC)n } \\
\text { (AC)n } \\
\text { (AT)n ... (TATC)n } \\
\text { (AC)n } \\
\text { (AC)n } \\
\text { (AC)n } \\
\text { (ATT)n } \\
\text { RFL } \text { F (H hal) }\end{array}$ & $\begin{array}{c}9 / 150-168 \\
9 / 156-176 \\
9 / 252-274 \\
8 / 233-247 \\
7 / 232-260 \\
5 / 203-211 \\
6 / 123-141 \\
10 / 142-159 \\
6 / 316-331 \\
2\end{array}$ & $\begin{array}{l}0.85 \\
0.86 \\
0.57 \\
0.65 \\
0.71 \\
0.71 \\
0.68 \\
0.86 \\
0.72 \\
0.36\end{array}$ \\
\hline
\end{tabular}

$* \mathrm{H}$ eterozygosity was determined in most cases by observation of 28 unrelated individuals, according to CEPH-G énéthon data.

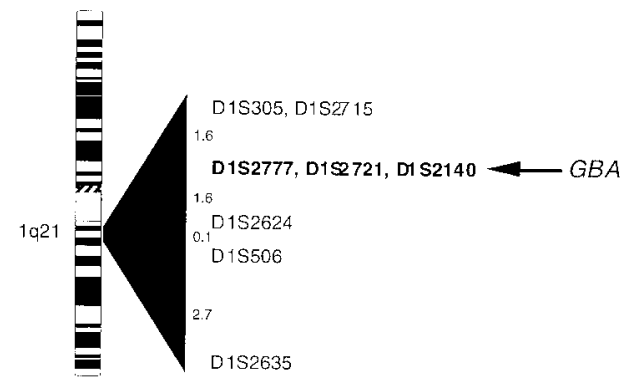

Fig. 1-Cytogenetic and genetic location of the GBA gene on chromosome 1. Markers useful for indirect diagnosis of $\mathrm{G}$ aucher disease are shown, with those located at $0 \mathrm{cM}$ of the GBA gene in bold (Cormand et al., 1997). Distances between markers (in $\mathrm{CM}$ ) are derived from the latest version of the G énéthon map (Dib et al., 1996)

$\Theta_{\max }=0.023 \quad Z_{\text {max }}=9.08 ; \quad D 1 S 2777 \quad \Theta_{\max }=0.00$ $Z_{\text {max }}=6.32 ; \quad D 1 S 2721 \quad \Theta_{\max }=0.00 \quad Z_{\max }=8.43$; D 1S2140 $\Theta_{\max }=0.00 \quad Z_{\max }=8.73 ; \quad D 1 S 2624$ $\Theta_{\max }=0.25 Z_{\max }=8 \cdot 49$. G enetic distances between the markers, shown in Fig. 1, are according to the G énéthon map ( $\mathrm{D}$ ib et al., 1996) and were checked on its online version in M ay 1997. Marker D 1S2140 was previously mapped at $0 \mathrm{cM}$ from D 1S2721 (Cormand et al., 1997). All markers belong to the MapPairs set from Research Genetics and were analysed according to the manufacturer's recommendations.

\section{RESULTS}

\section{General procedure}

The molecular diagnostic protocol consisted in the assessment of mutations N 370S, L 444P, and

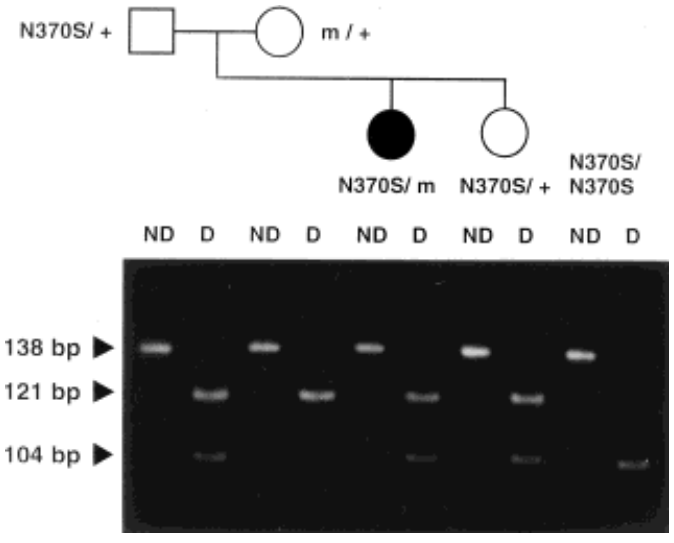

Fig. 2-R estriction analysis of amplified genomic DNA from members of family 1 . A GD patient, homozygous for N 370 , was included for comparison. Part of exon 9 of the GBA gene was amplified and incubated with $\mathrm{X}$ hol. D igestion products were separated by electrophoresis in a 12 per cent polyacrylamide gel and visualized with ethidium bromide. $+=$ wild-type allele; $\mathrm{m}=$ unknown mutated allele; $\mathrm{ND}=$ non-digested; $\mathrm{D}=$ digested

$\mathrm{D} 409 \mathrm{H}$, followed by analysis of co-segregation between the disease and highly polymorphic markers.

\section{Family 1}

A nalysis of the $N 370$ S mutation showed that the father, the affected individual, and her sister (for whom carrier detection or a hypothetical prenatal diagnosis could have been requested) were heterozygous for the mutation, as $X$ hol digestion of the PCR -amplified DNA produced two fragments of 121 and $104 \mathrm{bp}$, respectively (F ig. 2). Digestion of 
a

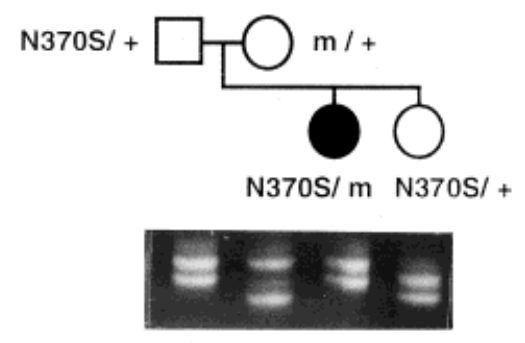

D1S2140

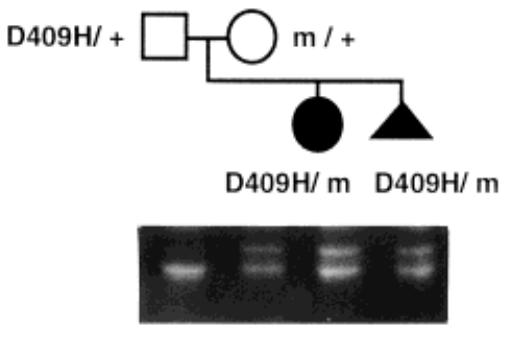

D1S2777

Fig. 3-Co-segregation analysis of $\mathrm{G}$ aucher disease with microsatellite markers from chromosome 1 q21 in families 1 (a) and 2 (b). The PCR products were resolved in a non-denaturing 6 per cent polyacrylamide gel and stained with ethidium bromide. $+=$ wild-type allele; $m=$ unknown mutated allele

DNA from the mother gave rise only to a 121-bp fragment, indicating that she was not a carrier of N 370S. Undigested DNA appeared as an upper band $(138 \mathrm{pb})$. The absence of this band in lanes corresponding to digested DNA shows that X hol digestion had taken place on the analysed D N A . A sample from a GD patient homozygous for N 370 S was added for comparison and, as expected, a single band of $104 \mathrm{bp}$ was observed.

Detection of the L 444P and D 409H mutations gave negative results in all the family members (data not shown).

Once the presence of N370S in the proband's sister had been established, it was necessary to determine whether she had inherited the same maternal GD allele as her affected sister. Eight polymorphic markers close to the GBA gene were tested, five of which (D 1S2721, D 1S305, D 1S2635, $D$ 1S2140, and D 1S506) were found to be informative. Figure 3a shows the results for the marker D 1S2140. The father's genotype was 1-2, and the mother's 1-3. Both sisters had inherited the same allele (2) from the father, as expected (because they were both heterozygous for $\mathrm{N} 370 \mathrm{~S}$ ) but received a different allele from the mother, which explains why the patient's sister was unaffected. The same information was obtained from other markers (data not shown).

\section{Family 2}

M utation analyses for both N 370 S and L 444P gave negative results in this family, while the affected individual, her father, and the fetus carried the $\mathrm{D} 409 \mathrm{H}$ mutation in one allele (data not shown). Five out of the eight markers analysed (D 1S2721, D 1S2715, D 1S2624, D 1S2777, and D 1S506) were informative for at least one of the parents. F igure $3 \mathrm{~b}$ shows the results for the marker D 1S2777, which was informative for the mother. The father was homozygous for allele 2, while the mother's genotype was 1-2. Both children had inherited the same maternal allele (1). Taken together, these data indicate that the fetus would have been affected.

\section{DISCUSSION}

Prenatal enzymatic diagnosis of $\mathrm{G}$ aucher disease allows the identification of an affected fetus but it cannot differentiate between the various clinical types of the disease. Besides, carrier detection is not always reliable due to overlapping of the enzymatic activity between some heterozygotes and normal individuals (Beutler and Grabowski, 1995). D N A analysis partially overcomes these limitations: mutation detection, in some cases, could predict the severity of disease (for example, N $370 S$ undoubtedly indicates type I) and allows the unambiguous identification of a heterozygous carrier.

A $n$ important drawback in the use of mutation analysis for prenatal diagnosis and carrier detection in G D is that it exhibits a high degree of allelic heterogeneity. In addition to the most prevalent $N 370 S$ and L444P (and D 409H in the Spanish population), more than 60 mutations have 
been reported as responsible for GD (Beutler and Gelbart, 1996). The identification of these uncommon mutations is too expensive and timeconsuming for routine use.

The method presented here, based on cosegregation analysis using highly polymorphic markers, allows diagnosis without the need to identify the mutations. A recommended molecular diagnostic protocol would consist in testing the presence of the most frequent mutations, followed by co-segregation analysis when one or both alleles remain unidentified. The reliability of this method is based on the fine genetic localization of the gene (Cormand et al., 1997) in relation to highly polymorphic markers (see Fig. 1). The use of markers known to be at a distance of $0 \mathrm{cM}$ from the gene (i.e., for which no recombination with the GBA gene was found), together with close markers at each side of GBA, greatly reduces the risk of misdiagnosis due to recombination. The high number of markers mapped to this region ensures that at least some of them would be informative in a given family. $M$ arkers at increasing distances from the gene become less reliable because of the higher probability of recombination. In our examples, the marker D 1S2635, $4.4 \mathrm{cM}$ distal from $G B A$, recombined in one of the meioses analysed in family 1.

The PKLR gene is known to be close to the GBA gene and polymorphisms within PKLR could also be used for co-segregation analysis. Glenn et al. (1994) concluded, after an indirect approach, that the distance between these genes is probably less than $0.2 \mathrm{cM}$. M oreover, the $340 \mathrm{~kb}$ long $Y A C$ 887h8 from the CEPH library has been shown to bear both the GBA and the PKLR genes (Cormand et al., 1997). Two polymorphisms have been described within the PKLR gene, a diallelic RFLP ( $K$ anno et al., 1992) and a trinucleotide repeat (Lenzner et al., 1994). The latter, because of its informativeness, could be included as one of the markers for the indirect molecular diagnosis protocol described here (see Table I).

The detection of mutation N $370 \mathrm{~S}$ is important not only for the diagnosis, but also for the prognosis of the disease. The detection method, based on PCR amplification and Xhol digestion, was improved by adding an internal digestion control in one of the PCR primers. N o fragment of $138 \mathrm{bp}$ should remain after the digestion (see Fig. 2 ) if the enzyme worked properly. The presence of a 121-bp or a 104-bp band indicates the absence or the presence of N 370 , respectively.
In the examples presented here, the second sister in family 1 was diagnosed as a carrier and the fetus in family 2 as affected. In fact, these two families had been previously subjected to extensive mutational analysis at the GBA gene. The genotype of the affected sib in family 1 was N 370S/1098insA, while the unaffected sister was N 370S/ + (C ormand et al., 1996). The index case in family 2 was genotyped as D 409H/R 120W (nt $475 \quad \mathrm{C} \rightarrow \mathrm{T}$ ) (Chabás et al., 1996), as was the affected fetus. The use of other markers, for example D 1S506 (data not shown), which was only informative for the father, would allow the indirect diagnosis in this family without performing $\mathrm{D} 409 \mathrm{H}$ analyses. For the marker D 1S506, the mother was homozygous for allele 1 and the father was heterozygous (1-2). Both the affected child and the fetus received the samel allele (2) from the father.

The use of DNA analysis for diagnostic purposes in a particular inherited disorder is only feasible when the disease-causing mutations can be easily determined or when intragenic or closely linked polymorphic markers are available. This approach is a good complement to classical prenatal enzymatic diagnosis and heterozygous detection. It is particularly useful in those cases where the enzymatic test gives ambiguous results, as in the detection of GD carriers, when only minimal amounts of sample are available, or in those laboratories where enzymatic analyses are not routinely performed. M oreover, it would be the most feasible prenatal diagnostic approach if the analysis of fetal cells in maternal blood (Cheung et al., 1996) becomes widely used.

\section{ACKNOWLEDGEMENTS}

We thank Dr F. M ulas, H ospital Infantil La Fe, Valencia, for providing us with samples from family 2 . We are also grateful to $\mathrm{R}$ obin $\mathrm{R}$ ycroft for revising the English. Bru Cormand is a recipient of a fellowship from CIRIT (Generalitat de Catalunya). This work was supported by $\mathrm{CICY} T$ (SA F 96-0329).

\section{REFERENCES}

Beutler, E., Gelbart, T. (1996). Glucocerebrosidase (G aucher disease), H um. M utat., 8, 207-213.

Beutler, E., G rabowski, G.A. (1995). G aucher disease. In: Scriver, C.R., Beaudet, A.L., Sly, W.S., Valle, D. (E ds). The M etabolic and M olecular Bases of I nherited Disease, 7th edn, N ew Y ork: 2641-2669. 
Beutler, E., G elbart, T., W est, C. (1990). The facile detection of the nt 1226 mutation of glucocerebrosidase by 'mismatched' PCR, Clin. Chim. A cta, 194, 161-166.

Beutler, E., W est, C., G elbart, T . (1992). Polymorphisms in the human glucocerebrosidase gene, Genomics, 12, 795-800.

Chabás, A., Cormand, B., Grinberg, D., Burguera, J.M ., Balcells, S., M erino, L., M ate, I., Sobrino, J .A ., Gonzàlez-D uarte, R ., Vilageliu, L. (1995). U nusual expression of $\mathrm{G}$ aucher's disease: cardiovascular calcifications in three sibs homozygous for the $\mathrm{D} 409 \mathrm{H}$ mutation, J. M ed. Genet., 32, 740-742.

Chabás, A., Cormand, B., Balcells, S., G onzàlezDuarte, R., Casanova, C., Colomer, J., Vilageliu, L., Grinberg, D. (1996). N euronopathic and nonneuronopathic presentation of $\mathrm{G}$ aucher disease in patients with the third most common mutation (D 409H ) in Spain, J . Inher. M etab. D is., 19, 798-800.

Cheung, M.-C., Goldberg, J.D., K an, Y.W. (1996). Prenatal diagnosis of sickle cell anaemia and thalassaemia by analysis of fetal cells in maternal blood, N ature $G$ enet., 14, 264-268.

Cormand, B., Vilageliu, L., Burguera, J.M., Balcells, S., G onzàlez-D uarte, R ., Grinberg, D., Chabás, A . (1995). Gaucher disease in Spanish patients: analysis of eight mutations, H um. M utat., 5, 303-309.

Cormand, B., Vilageliu, L., Balcells, S., G onzàlezDuarte, R., Chabás, A., Grinberg, D. (1996). Two novel (1098insA and $Y 313 \mathrm{H}$ ) and one rare (R 359Q) mutations detected in exon 8 of the $\beta$-glucocerebrosidase gene in Gaucher's disease patients, $\mathrm{H}$ um. M utat., 7, 272-274.

Cormand, B., M ontfort, M ., Chabás, A., Vilageliu, L., Grinberg, D. (1997). G enetic fine localization of the $\beta$-glucocerebrosidase (GBA) and prosaposin (PSAP) genes; implications for $\mathrm{G}$ aucher disease, $\mathrm{H}$ um. G enet., $100,75-79$

Dahl, N., W adelius, C., A nneren, G., G ustavson, K .H (1992). M utation analysis for prenatal diagnosis and heterozygous detection of Gaucher disease type-III (N orrbottnian type), Prenat. Diagn., 12, 603-608.

Dib, C., Faure, S., Fizames, C., Samson, D., D rouot, N ., V ignal, A., M illasseau, P., M arc, S., H azan, J., Seboun, E., Lathrop, M ., G yapay, G., M orissette, J., W eissenbach, J. (1996). A comprehensive genetic map of the human genome based on 5,264 microsatellites, N ature, 380, 152-154.

Horowitz, M., Wilder, S., H orowitz, Z., R einer, O., Gelbart, T., Beutler, E. (1989). The human glucocerebrosidase gene and pseudogene: structure and evolution, Genomics, 4, 87-96.

G lenn, D., G elbart, T., B eutler, E. (1994). Tight linkage of pyruvate kinase (PKLR) and glucocerebrosidase (GBA) genes, H um. Genet., 93, 635-638.

$\mathrm{K}$ anno, H., $\mathrm{F}$ ujii, H., H irono, A., O mine, M ., M iwa, S. (1992). Identical point mutations of the R-type pyruvate kinase (PK) CDNA found in unrelated PK variants associated with hereditary hemolytic anemia, Blood, 79, 1347-1350.

Lenzner, C., J acobasch, G., Reis, A., Thiele, B., N ürnberg, P. (1994). Trinucleotide repeat polymorphism at the PK LR locus, H um. M ol. Genet., 3, 523.

M iller, S.A ., D yke, D .D ., Polesky, H .F . (1988). A simple salting out procedure for extracting DNA from human nucleated cells, N ucleic A cids Res., 16, 1215.

Schneider, E.L., Ellis, W.G., Brady, R.O., M cCollough, J .R ., E pstein, C.J . (1972). Infantile (type II) G aucher's disease: in utero diagnosis and fetal pathology, J. Pediatr., 81, 1134-1139.

Sidransky, E., T suji, S., M artin, B.M., Stubblefield, B., Ginns, E.I. (1992). DNA mutation analysis of G aucher patients, Am. J. M ed. Genet., 42, 331-336.

Zimran, A., Elstein, D., A brahamov, A., K uhl, W., Brown, K.H., Beutler, E. (1995). Prenatal molecular diagnosis of $\mathrm{G}$ aucher disease, Prenat. Diagn., 15, 1185-1188. 